\title{
Corn Yield Loss Estimates Due to Diseases in the United States and Ontario, Canada from 2012 to 2015
}

Daren S. Mueller, Department of Plant Pathology and Microbiology, lowa State University, Ames 50011; Kiersten A. Wise, Department of Botany and Plant Pathology, Purdue University, West Lafayette, IN 47907; Adam J. Sisson, Department of Plant Pathology and Microbiology, lowa State University, Ames 50011; Tom W. Allen, Delta Research and Extension Center, Mississippi State University, Stoneville 38776; Gary C. Bergstrom, Department of Plant Pathology and Plant-Microbe Biology Section, Cornell University, Ithaca, NY 14853; D. Bruce Bosley, Colorado State University Extension, Fort Collins 80523; Carl A. Bradley, Department of Plant Pathology, University of Kentucky Research and Education Center, Princeton 42445; Kirk D. Broders, Department of Bioagricultural Sciences and Pest Management, Colorado State University, Fort Collins 80523; Emmanuel Byamukama, Department of Plant Pathology, South Dakota State University, Brookings 57007; Martin I. Chilvers, Department of Plant, Soil and Microbial Sciences, Michigan State University, East Lansing 48824; Alyssa Collins, Department of Plant Pathology and Environmental Microbiology, Southeast Agricultural Research and Extension Center, The Pennsylvania State University, Manheim 17545; Travis R. Faske, Lonoke Research and Extension Center, University of Arkansas, Lonoke 72086; Andrew J. Friskop, Department of Plant Pathology, North Dakota State University, Fargo 58102; Ron W. Heiniger, Department of Crop Science, North Carolina State University, Plymouth 27962; Clayton A. Hollier, Department of Plant Pathology and Crop Physiology, Louisiana State University, Baton Rouge 70803; David C. Hooker, Department of Plant Agriculture, University of Guelph, Ridgetown, Ontario, Canada NOP 2C0; Tom Isakeit, Department of Plant Pathology and Microbiology, Texas A\&M University, College Station 77843; Tamra A. Jackson-Ziems, Department of Plant Pathology, University of Nebraska-Lincoln, 68588; Douglas J. Jardine, Department of Plant Pathology, Kansas State University, Manhattan 66506; Heather M. Kelly, Department of Entomology and Plant Pathology, West Tennessee Research and Education Center, University of Tennessee, Jackson 38301; Kasia Kinzer, Department of Plant Pathology, North Dakota State University, Fargo 58102; Steve R. Koenning, Department of Plant Pathology, North Carolina State University, Raleigh 27695; Dean K. Malvick, Department of Plant Pathology, University of Minnesota, St. Paul 55108; Marcia McMullen, Department of Plant Pathology, North Dakota State University, Fargo 58102; Ron F. Meyer, Colorado State University Extension, Burlington 80807; Pierce A. Paul, Department of Plant Pathology, The Ohio State University, Wooster 44691; Alison E. Robertson, Department of Plant Pathology and Microbiology, lowa State University, Ames 50011; Gregory W. Roth, Department of Plant Science, The Pennsylvania State University, University Park 16802; Damon L. Smith, Department of Plant Pathology, University of Wisconsin-Madison, Madison 53706; Connie A. Tande, Plant Science Department, South Dakota State University, Brookings 57007; Albert U. Tenuta, Ontario Ministry of Agriculture, Food and Rural Affairs, Ridgetown, Ontario, Canada, NOP 2C0; Paul Vincelli, Department of Plant Pathology, University of Kentucky, Lexington 40546; and Fred Warner, Department of Plant, Soil and Microbial Sciences, Michigan State University, East Lansing 48824 [*see Erratum]

Accepted for publication 26 August 2016.

\section{ABSTRACT}

Annual decreases in corn yield caused by diseases were estimated by surveying members of the Corn Disease Working Group in 22 corn-producing states in the United States and in Ontario, Canada, from 2012 through 2015. Estimated loss from each disease varied greatly by state and year. In general, foliar diseases such as northern corn leaf blight, gray leaf spot, and Goss's wilt commonly caused the largest estimated yield loss in the northern United States and Ontario during non-drought years. Fusarium stalk rot and plant-parasitic nematodes caused the most estimated loss in

\section{INTRODUCTION}

Corn (Zea mays L.) diseases reduce yield and grain quality in the United States and Canada every year. Diseases of importance vary annually and from location to location. Occurrence of corn diseases that cause yield loss are influenced by many factors, including environmental conditions, crop production practices,

\footnotetext{
* Erratum: The author list was corrected on 5 December 2016 to include an inadvertently omitted author.
}

Corresponding author: Daren S. Mueller. Email: dsmuelle@iastate.edu. the southern-most United States. The estimated mean economic loss due to yield loss by corn diseases in the United States and Ontario from 2012 to 2015 was $\$ 76.51$ USD per acre. The cost of disease-mitigating strategies is another potential source of profit loss. Results from this survey will provide scientists, breeders, government, and educators with data to help inform and prioritize research, policy, and educational efforts in corn pathology and disease management.

previous disease history, hybrid selection, and susceptibility to disease (Munkvold and White 2016).

Previous estimates of annual yield loss caused by corn diseases in the United States ranged from 2 to $15 \%$ (Munkvold and White 2016). Catastrophic losses due to disease in corn are rare but have occurred, notably in 1970 when Race T of Bipolaris maydis resulted in a southern corn leaf blight epidemic that reduced corn yield by $20 \%$ in the United States (Ullstrup 1972). Yield loss to diseases may also go unnoticed or not be recognized due to misdiagnosis. Under these circumstances, yield reduction from stalk rots can take place through reduced ear size, poor grain fill, and early eardrop (Jardine 2006), and plant-parasitic nematodes can cause aboveground symptoms that may be mistakenly 
attributed to environmental conditions (Norton and Nyvall 2011). Some ear and stalk rot causing pathogens such as Aspergillus, Fusarium, and Gibberella species produce secondary metabolites known as mycotoxins that can make grain unsafe for animal or human consumption (Wise et al. 2016; Bennett and Klich 2003). In the United States, certain field-corn disease symptoms are often observed on plants but generally cause only a small reduction in corn yield. Examples of frequently occurring diseases where yield reduction is considered negligible include common rust (Puccinia sorghi) or eyespot (Aureobasidium zeae) on hybrid field corn (Wise et al. 2016).

Corn diseases are important because resultant grain loss decreases food, feed, and fuel production. The total corn production in the entire United States and Ontario, Canada, from 2012 to 2015 was nearly 54 billion bushels, which was valued at over \$244 billion (USDA-NASS; Kulasekera 2015). Consequently, even if only the lowest estimated annual yield loss of $2 \%$ was realized, the loss during these years would be more than 1 billion bushels, translating to nearly $\$ 5$ billion in lost revenue.

Annual soybean (Glycine max) disease loss estimates began in 1974 in the southern United States and in 1996 for the northern United States (Wrather et al. 1995; Wrather and Koenning 2009). These data have been published, often as summaries for 3- to 4year spans (Koenning and Wrather 2010; Wrather et al. 2003; Wrather and Koenning 2006). However, the authors are not aware of any published multiyear summary of estimated corn yield losses in the United States and Ontario, Canada.

The goal of this survey was to determine the relative importance of the various corn diseases regionally and over time, equipping researchers, breeders, government, and Extension specialists with data to help prioritize educational opportunities, research investigations, and funding requests. Thus, the objective of this survey was to determine the annual estimated disease losses in field corn for each of the top corn-producing states in the United States and Ontario, Canada.

\section{DATA COLLECTION AND LOSS ESTIMATE DETERMINATION}

The disease loss estimates in this publication were provided by members of the United States and Canadian Corn Disease Working Group after the end of each growing season from 2012 to 2015. For the purpose of this survey, states and provinces were broken up into a "southern" and a "northern" geographic region. States and provinces included in the northern region were Illinois, Indiana, Iowa, Michigan, Minnesota, Nebraska, New York, North Dakota, Ohio, Pennsylvania, South Dakota, Wisconsin, and Ontario, Canada. The southern region consisted of Arkansas, Colorado, Kansas, Kentucky, Louisiana, Mississippi, Missouri, North Carolina, Tennessee, and Texas. A list of diseases was provided to pathologists in these states and provinces each year, and respondents were asked to estimate losses for each disease listed, and to also include information about diseases not listed on the form. Respondents used various methods to obtain disease loss information, and most individuals relied on more than one. It is important to note that methods for estimating disease loss varied by state and province. The estimates are based on statewide or provincial disease surveys, feedback from university Extension, industry, and farmer representatives, plant disease diagnostic clinic samples, research plots, "pure guess," and/or personal experience with disease losses. Disease loss estimates include grain from hybrid corn. Data were unavailable for Missouri in 2013.

\begin{tabular}{|c|c|c|c|c|c|}
\hline \multicolumn{6}{|c|}{$\begin{array}{c}\text { TABLE } 1 \\
\text { Total corn production (1,000 bu) in the United States and Ontario, Canada from } 2012 \text { to } 2015 .\end{array}$} \\
\hline State or province & 2012 & 2013 & 2014 & 2015 & Total \\
\hline Arkansas & 123,710 & 161,820 & 99,110 & 80,545 & 465,185 \\
\hline Colorado & 134,330 & 128,380 & 147,460 & 134,900 & 545,070 \\
\hline Illinois & $1,286,250$ & $2,100,400$ & $2,350,000$ & $2,012,500$ & $7,749,150$ \\
\hline Indiana & 596,970 & $1,031,910$ & $1,084,760$ & 822,000 & $3,535,640$ \\
\hline Kentucky & 104,040 & 243,100 & 225,940 & 225,320 & 798,400 \\
\hline Louisiana & 91,690 & 115,910 & 71,370 & 66,690 & 345,660 \\
\hline Michigan & 314,160 & 345,650 & 355,810 & 335,340 & $1,350,960$ \\
\hline Minnesota & $1,374,450$ & $1,294,260$ & $1,177,800$ & $1,428,800$ & $5,275,310$ \\
\hline Mississippi & 131,175 & 146,080 & 89,725 & 85,750 & 452,730 \\
\hline Missouri & 247,500 & 435,200 & 628,680 & 437,360 & $1,748,740$ \\
\hline Ohio & 438,000 & 649,020 & 610,720 & 498,780 & $2,196,520$ \\
\hline Ontario & 338,500 & 354,600 & 299,200 & 348,000 & $1,340,300$ \\
\hline Pennsylvania & 131,000 & 159,140 & 158,620 & 138,180 & 586,940 \\
\hline South Dakota & 535,300 & 802,820 & 787,360 & 799,770 & $2,925,250$ \\
\hline Tennessee & 81,600 & 126,360 & 141,120 & 116,800 & 465,880 \\
\hline Texas & 199,950 & 265,200 & 294,520 & 265,950 & $1,025,620$ \\
\hline Wisconsin & 396,000 & 439,350 & 485,160 & 492,000 & $1,812,510$ \\
\hline Total & $10,678,155$ & $13,670,000$ & $14,060,325$ & $13,561,735$ & $51,970,215$ \\
\hline Southern U.S.y & $1,585,185$ & $2,248,170$ & $2,367,085$ & $2,075,965$ & $8,276,405$ \\
\hline $\begin{array}{l}\text { Northern U.S. }{ }^{\mathrm{z}} \text { and } \\
\text { Ontario, Canada }\end{array}$ & $9,092,970$ & $11,421,830$ & $11,693,240$ & $11,485,770$ & $43,693,810$ \\
\hline
\end{tabular}

y Southern United States includes Arkansas, Colorado, Kansas, Kentucky, Louisiana, Mississippi, Missouri, North Carolina, Tennessee, and Texas.

${ }^{z}$ Northern United States includes Illinois, Indiana, Iowa, Michigan, Minnesota, Nebraska, New York, North Dakota, Ohio, Pennsylvania, South Dakota, and Wisconsin. 
Yearly per-acre corn production totals and crop value for corn grown in each state or province were determined using data from the United States Department of Agriculture's National Agricultural Statistics Service (USDA-NASS) and the Ontario Ministry of Agriculture, Food, and Rural Affairs (OMAFRA) (Kulasekera 2015). Total production for Ontario, Canada in 2015 was estimated by OMAFRA; total Ontario crop value in 2015 was determined by applying the United States national marketing year corn price to the total estimated production value. Disease loss values were determined based on yield before estimated losses \{[(100 percent estimated disease loss)/100]/bushels harvested $\}$ for each state or province. Total bushels lost per disease (percent loss $\times$ yield before estimated loss) was then calculated for each state or province. Losses in crop value were also determined in a similar fashion.

\section{RESULTS AND IMPLICATIONS}

This survey represents $96.7 \%$ of the total corn produced in the United States and Ontario between 2012 and 2015. Total annual production in these states and province ranged from a low of 10.68 billion bushels in 2012 to a high of 14.06 billion bushels in 2014 (Table 1). Individual state and provincial production values also varied widely from year to year.

Estimates of total corn production losses due to diseases differed greatly by state or province and year, from $0.02 \%$ in Colorado in 2015 to $25.08 \%$ in Ohio in 2012. States that produced more corn generally also had greater estimates of loss due to disease. The estimated corn production losses per year were 10.9\%, 7.5\%,
$10.4 \%$, and $13.5 \%$ for $2012,2013,2014$, and 2015 , respectively. Estimates do not account for potential grain contamination or rejection as a result of mycotoxins, thus the estimates presented here may be conservative.

A more useful indicator than percent production loss, is loss of bushels of corn. A $1 \%$ loss during a drought-affected year such as 2012 where mean yield per acre is reduced may be different than a $1 \%$ loss during a more productive year such as 2014. Similarly, a $1 \%$ loss in a major production state differs in total magnitude compared to a $1 \%$ loss in a state that produces less corn. Total estimated bushels lost were 1.3 billion in 2012, 1.1 billion in 2013, 1.6 billion in 2014, and 2.1 billion in 2015 (Table 2).

Estimated corn yield loss due to root rots, seedling blights, and plant-parasitic nematodes can be found in Table 3, while corn yield losses due to foliar and aboveground diseases can be found in Table 4. Corn yield losses due to stalk rots and ear rots can be found in Tables 5 and 6, respectively. Finally, estimates of mycotoxin contaminated grain can be found in Table 7 . The estimated impact that each specific disease had on corn production in the United States and Ontario, Canada, was highly variable by disease and year, ranging from approximately 21,000 bushels yield loss due to Stewart's disease (Pantoea stewartii) in 2014 to more than 551 million bushels lost due to northern corn leaf blight (Setosphaeria turcica) in 2015 (Table 8).

The most destructive diseases in the 12 northern-most United States and Ontario, Canada, varied little by year (Table 9). Yield loss estimates for northern corn leaf blight were greatest in 2014 and 2015 and the second greatest in 2013, while estimates were

\begin{tabular}{|c|c|c|c|c|c|}
\hline \multicolumn{6}{|c|}{$\begin{array}{l}\text { TABLE } 2 \\
\text { Total estimated corn yield loss (bushels) due to diseases in the United States and Ontario, Canada from } 2012 \text { to } 2015 \text {, excludi } \\
\text { grain contamination or rejection due to mycotoxins. }\end{array}$} \\
\hline State or province & 2012 & $2013^{x}$ & 2014 & 2015 & Total \\
\hline Arkansas & $3,432,857$ & $1,222,821$ & 930,375 & $1,972,160$ & $7,558,214$ \\
\hline Colorado & $5,991,738$ & 298,534 & $5,048,015$ & 26,985 & $11,365,273$ \\
\hline Illinois & $214,625,146$ & $200,147,645$ & $230,999,451$ & $218,652,993$ & $864,425,235$ \\
\hline Kansas & $106,333,676$ & $67,493,367$ & $71,916,351$ & $115,142,013$ & $360,885,406$ \\
\hline Kentucky & $5,591,191$ & $2,071,701$ & $1,066,933$ & $10,839,732$ & $19,569,556$ \\
\hline Louisiana & $1,137,132$ & 917,093 & $1,116,289$ & 769,033 & $3,939,547$ \\
\hline Michigan & $68,961,951$ & $45,356,787$ & $80,285,110$ & $66,312,893$ & $260,916,741$ \\
\hline Minnesota & $44,703,330$ & $161,928,119$ & $162,436,686$ & $111,685,175$ & $480,753,310$ \\
\hline Mississippi & $2,472,478$ & $1,700,959$ & $1,307,223$ & $2,710,519$ & $8,191,179$ \\
\hline North Dakota & $4,565,535$ & $4,121,249$ & $9,902,860$ & $6,687,347$ & $25,276,991$ \\
\hline Ohio & $146,623,599$ & $69,797,145$ & $135,060,926$ & $117,149,859$ & $468,631,528$ \\
\hline Ontario & $24,152,668$ & $25,179,372$ & $28,726,348$ & $35,175,512$ & $113,233,900$ \\
\hline Pennsylvania & $12,310,360$ & $25,071,136$ & $16,611,993$ & $12,671,528$ & $66,665,017$ \\
\hline South Dakota & $134,830,195$ & $43,768,632$ & $19,857,552$ & $92,631,250$ & $291,087,629$ \\
\hline Tennessee & $5,393,603$ & $3,014,424$ & $3,292,607$ & $3,525,538$ & $15,226,173$ \\
\hline Texas & $1,571,871$ & 425,000 & 353,849 & 319,523 & $2,670,243$ \\
\hline Wisconsin & $89,889,571$ & $26,013,839$ & $49,216,033$ & $53,152,355$ & $218,271,796$ \\
\hline Total & $1,301,576,212$ & $1,067,131,227$ & $1,631,556,663$ & $2,118,274,291$ & $6,118,538,393$ \\
\hline Southern U.S.y & $160,023,002$ & $79,395,016$ & $119,684,822$ & $161,949,824$ & $521,052,664$ \\
\hline $\begin{array}{l}\text { Northern U.S. }{ }^{\mathrm{a}} \text { and } \\
\text { Ontario, Canada }\end{array}$ & $1,141,553,211$ & $987,736,211$ & $1,511,871,841$ & $1,956,324,467$ & $5,597,485,729$ \\
\hline
\end{tabular}

${ }^{\mathrm{x}}$ In 2013, disease loss estimate data was not available in Missouri.

y Southern United States includes Arkansas, Colorado, Kansas, Kentucky, Louisiana, Mississippi, Missouri, North Carolina, Tennessee, and Texas.

${ }^{z}$ Northern United States includes Illinois, Indiana, Iowa, Michigan, Minnesota, Nebraska, New York, North Dakota, Ohio, Pennsylvania, South

Dakota, and Wisconsin. 


\begin{tabular}{|c|c|c|c|c|c|}
\hline \multicolumn{6}{|c|}{ 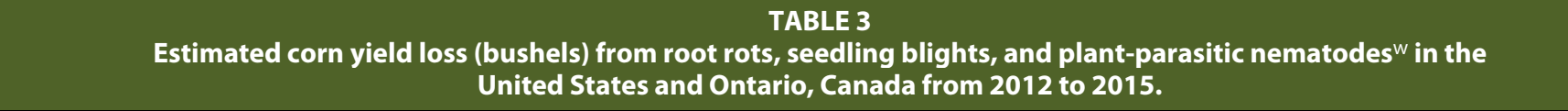 } \\
\hline State or province & 2012 & $2013^{x}$ & 2014 & 2015 & Total \\
\hline Arkansas & 63,571 & 81,521 & 60,024 & 90,769 & 295,886 \\
\hline Colorado & 701,609 & 77,207 & 0 & 0 & 778,816 \\
\hline Illinois & $22,513,127$ & $27,606,572$ & $11,614,498$ & $14,502,494$ & $76,236,691$ \\
\hline Indiana & $14,355,055$ & $17,370,395$ & $20,094,715$ & $7,682,243$ & $59,502,408$ \\
\hline Kansas & $24,127,342$ & $28,631,818$ & $19,207,302$ & $34,765,101$ & $106,731,563$ \\
\hline Kentucky & 0 & 147,103 & 136,204 & 354,240 & 637,547 \\
\hline Louisiana & 46,414 & 58,414 & 362,431 & 337,295 & 804,554 \\
\hline Michigan & $34,480,976$ & $25,415,441$ & $34,887,609$ & $32,132,231$ & $126,916,257$ \\
\hline Minnesota & $2,128,730$ & $42,229,455$ & $25,464,497$ & $17,715,580$ & $87,538,262$ \\
\hline Mississippi & 13,365 & 29,556 & 19,117 & 1,769 & 63,807 \\
\hline North Dakota & 0 & 0 & $3,268,591$ & $1,671,837$ & $4,940,428$ \\
\hline Ohio & $6,021,623$ & 71,882 & $2,311,921$ & $3,141,242$ & $11,546,668$ \\
\hline Ontario & $5,874,973$ & $6,076,470$ & $6,230,601$ & $6,897,159$ & $25,079,203$ \\
\hline Pennsylvania & 429,931 & 36,842 & 403,034 & 316,788 & $1,186,595$ \\
\hline South Dakota & 268,052 & 253,977 & 161,444 & $13,386,019$ & $14,069,491$ \\
\hline Tennessee & 8,699 & 38,812 & 28,883 & 24,065 & 100,459 \\
\hline Texas & 100,761 & 79,688 & 0 & 0 & 180,448 \\
\hline Wisconsin & $24,294,479$ & $7,026,994$ & $3,206,256$ & $4,633,795$ & $39,161,524$ \\
\hline Total & $223,146,406$ & $300,420,775$ & $162,778,077$ & $179,505,663$ & $865,850,921$ \\
\hline Southern U.S.y & $33,671,541$ & $30,163,962$ & $27,095,599$ & $44,932,856$ & $135,863,958$ \\
\hline $\begin{array}{l}\text { Northern U.S. }{ }^{\mathrm{z}} \text { and } \\
\text { Ontario, Canada }\end{array}$ & $189,474,865$ & $270,256,813$ & $135,682,478$ & $134,572,807$ & $729,986,963$ \\
\hline
\end{tabular}

${ }^{w}$ Diseases include those caused by Fusarium spp.; Pythium spp.; Rhizoctonia spp.; Phoma terrestris; and plant-parasitic nematodes (Belonolaimus longicaudatus., Helicotylenchus spp., Heterodera zeae, Hoplolaimus spp., Longidorus breviannulatus, Meloidogyne spp., Paratrichodorus spp., Pratylenchus spp., Tylenchorhynchus spp.)

${ }^{x}$ In 2013, disease loss estimate data was not available in Missouri.

y Southern United States includes Arkansas, Colorado, Kansas, Kentucky, Louisiana, Mississippi, Missouri, North Carolina, Tennessee, and Texas.

${ }^{\mathrm{z}}$ Northern United States includes Illinois, Indiana, Iowa, Michigan, Minnesota, Nebraska, New York, North Dakota, Ohio, Pennsylvania, South

Dakota, and Wisconsin.

lower in the drought year of 2012. Gray leaf spot (Cercospora zeae-maydis) and Goss's wilt (Clavibacter michiganensis subsp. nebraskensis) were in the top four most production-limiting diseases every year except 2012. Fusarium stalk rot (Fusarium verticillioides) was always the fifth or sixth greatest cause of disease-related yield loss, while Fusarium and Aspergillus ear rots (Fusarium and Aspergillus spp.) ranked as the top diseases causing yield loss in 2012. Trends also emerged in the 10 southern-most United States (Table 10). For example, Fusarium stalk rot was always ranked first or second in terms of causing the greatest estimated yield loss, while plant-parasitic nematodes always ranked in the top three most important pathogens causing yield loss.

Environmental conditions fluctuated widely from year to year and greatly impacted final yield as well as disease incidence and severity. This is most evident when comparing 2012, a drought year, to the 2013 to 2015 yield trends. Corn yield during 2012 was approximately 3 billion bushels less than that of any other year. Environment also influenced diseases and associated yield loss estimates. For example, 2015 summer precipitation in the Midwest was the fourth greatest on record, while foliar diseases in 2015 resulted in double the yield loss compared to 2013, despite the fact that total grain production was greater in 2013 than 2015 (NOAA 2015).
Overall, from 2012 to 2015 the total estimated economic loss due to disease was $\$ 27.4$ billion in the United States and Ontario, Canada (Table 11). Yearly estimated economic losses were almost twice as great in 2012 than in 2013, and averaged approximately $\$ 6.85$ billion annually during this survey period. It is interesting to note that estimated economic loss was greatest in 2012, when production was reduced compared to 2013, 2014, or 2015, in part because of greater per bushel prices received during 2012. The next highest year in terms of economic loss was 2015, despite the fact that nearly 817 million more bushels were estimated to have been lost due to disease than in 2012. During this survey, the United States national corn marketing prices per bushel were as follows: $\$ 6.89$ in 2012, \$4.46 in 2013, \$3.70 in 2014, and \$3.60 in 2015 (USDA-NASS). Thus, the estimated economic losses due to diseases in corn were as follows: $\$ 94.71$ /acre in 2012, $\$ 53.26$ /acre in 2013, $\$ 68.95 /$ acre in 2014 , and $\$ 88.35$ /acre in 2015 . The average estimated yield loss due to corn diseases during the four years of this survey (2012 to 2015) was \$76.32/acre. This is important to note, as these values may be larger than, or approach, the profit margins per acre in some years. For example, average corn production expenses for Iowa in 2014 were $\$ 722.21$ per acre, while crop value was $\$ 793.00$ per acre (Plastina and Johanns 2016). When production expenses are subtracted from crop value, $\$ 70.79$ remains, a value that is similar to the four-year average of estimated yield loss due to corn diseases. 
TABLE 4

Estimated corn yield loss (bushels) from foliar and other aboveground diseasesw (not including stalk and ear rots) in the United States and Ontario, Canada from 2012 to 2015.

\section{State or province}

Arkansas

Colorado

Illinois

Indiana

Iowa

Kansas

Kentucky

Louisiana

Michigan

Minnesota

Mississippi

Missouri

Nebraska

New York

North Carolina

North Dakota

Ohio

Ontario

Pennsylvania

South Dakota

Tennessee

Texas

Wisconsin

Total

Southern U.S.

Northern U.S. ${ }^{\mathrm{z}}$ and

Ontario, Canada

\section{4}

$1,106,143$

$2,483,695$

$96,056,009$

$6,009,093$

$21,807,673$

288,950

$1,918,546$

997,892

$17,240,488$

$14,191,533$

$1,764,147$

$5,463,576$

$80,403,556$

$3,512,474$

560,650

$4,352,192$

$70,271,757$

$13,128,027$

$10,934,580$

$87,519,004$

$2,705,501$

$1,390,501$

$29,153,374$

$473,259,360$

$18,679,600$

$454,579,760$ $2013^{x}$

586,954

92,649

$138,032,859$

$27,684,066$

$18,662,526$

$3,371,811$

$1,605,875$

683,438

$12,903,224$

$73,100,644$

$1,361,063$

$$
\text { - }
$$

$80,963,828$

$4,538,254$

$1,019,843$

$4,041,225$

$58,943,006$

$12,798,565$

$22,565,864$

$26,413,565$

$2,755,675$

239,063

$9,586,495$

$501,950,491$

$11,716,370$

$490,234,120$
530,214

472,775

2015

$1,592,581$

13,493

$160,021,966$

$53,546,505$

$320,177,472$

$6,956,106$

749,123

732,112

$36,675,599$

$95,424,852$

$1,195,253$

$11,226,429$

$44,257,356$

$2,256,877$

$1,895,879$

$6,569,544$

$93,222,616$

$13,379,395$

$15,192,614$

$10,332,385$

$3,047,106$

265,386

$37,726,948$

$915,854,511$

$27,070,383$

$888,784,129$
$152,833,980$

$147,563,084$

$480,548,680$

$23,431,678$

$9,611,701$

411,500

$26,107,438$

$54,687,224$

$2,485,829$

$7,564,403$

$134,764,085$

$1,537,354$

$2,280,383$

$3,343,673$

$86,291,773$

$21,304,558$

$12,234,059$

$65,591,492$

$3,320,985$

239,643

$30,474,017$

$1,268,233,613$

$50,952,195$

$1,217,281,418$

\footnotetext{
${ }^{\mathrm{w}}$ Diseases include those caused by Bipolaris maydis; Brome mosaic virus; Cercospora zea maydis; Clavibacter michiganensis subsp. nebraskensis Cochliobolus carbonum; Colletotrichum graminicola; Kabatiella zeae; Maize chlorotic mottle virus; Maize dwarf mosaic virus + Maize chlorotic dwarf virus complex; Pantoea stewartii; Peronosclerospora sorghi; Physoderma maydis; Pseudomonas syringae; Puccinia polysora; Puccinia sorghi; Sclerophthora macrospora; Setosphaeira turcica; Sphacelotheca reiliana; Stenocarpella macrospora; Sugarcane mosaic virus; Ustilago maydis; and Wheat streak mosaic virus.

x In 2013, disease loss estimate data was not available in Missouri.

y Southern United States includes Arkansas, Colorado, Kansas, Kentucky, Louisiana, Mississippi, Missouri, North Carolina, Tennessee, and Texas.

${ }^{z}$ Northern United States includes Illinois, Indiana, Iowa, Michigan, Minnesota, Nebraska, New York, North Dakota, Ohio, Pennsylvania, South Dakota, and Wisconsin.
} 
TABLE 5

Estimated corn yield loss (bushels) from stalk rot diseasesw in the United States and Ontario, Canada from 2012 to 2015.

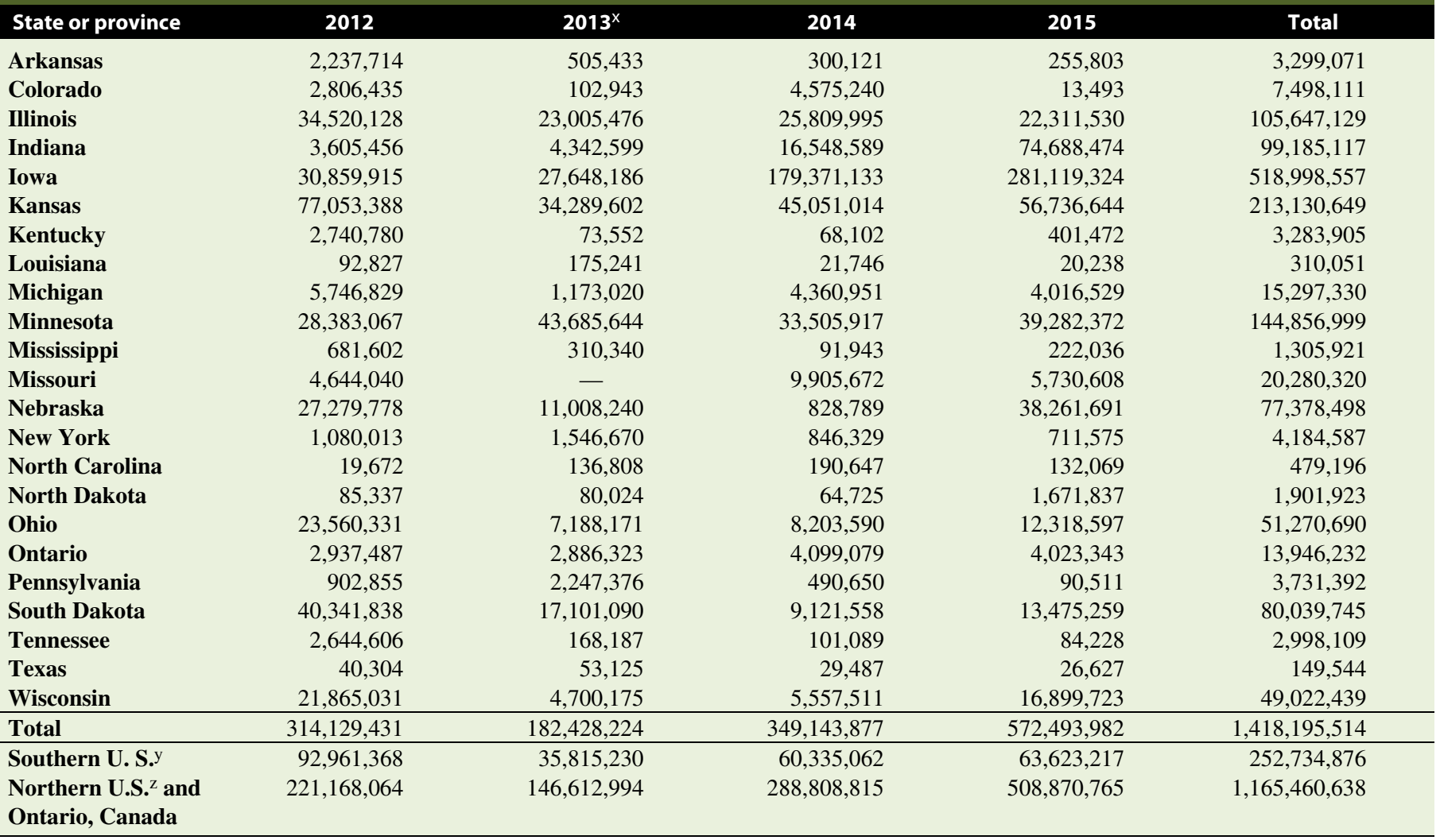

${ }^{w}$ Diseases include those caused by Colletotrichum graminicola; Erwinia spp.; Fusarium spp.; Gibberella zeae; Macrophomina phaseolina;

Physoderma maydis; Pythium aphanidermatum; and Stenocarpella maydis.

${ }^{x}$ In 2013, disease loss estimate data was not available in Missouri.

y Southern United States includes Arkansas, Colorado, Kansas, Kentucky, Louisiana, Mississippi, Missouri, North Carolina, Tennessee, and Texas.

${ }^{\text {z } N o r t h e r n ~ U n i t e d ~ S t a t e s ~ i n c l u d e s ~ I l l i n o i s, ~ I n d i a n a, ~ I o w a, ~ M i c h i g a n, ~ M i n n e s o t a, ~ N e b r a s k a, ~ N e w ~ Y o r k, ~ N o r t h ~ D a k o t a, ~ O h i o, ~ P e n n s y l v a n i a, ~ S o u t h ~}$

Dakota, and Wisconsin. 
TABLE 6

Estimated corn yield loss (bushels) from ear rot diseasesw in the United States and Ontario, Canada from 2012 to 2015.

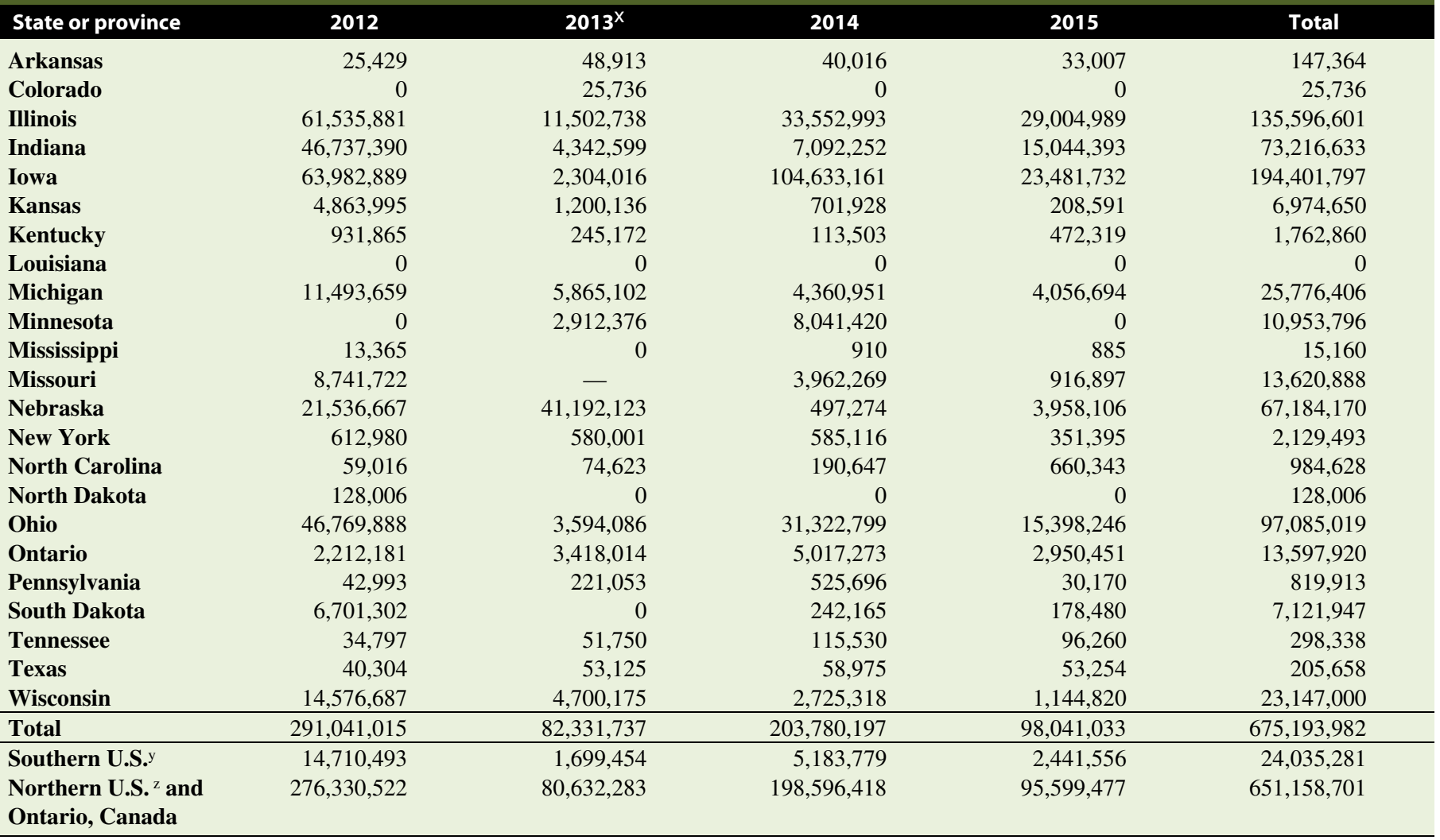

${ }^{\text {w }}$ Diseases include those caused by Aspergillus flavus and other Aspergillus spp.; Cladosporium spp.; Fusarium graminearum; Fusarium spp.;

Nigrospora oryzae; Penicillium spp.; Stenocarpella maydis; and Trichoderma viride.

x In 2013, disease loss estimate data was not available in Missouri.

y Southern United States includes Arkansas, Colorado, Kansas, Kentucky, Louisiana, Mississippi, Missouri, North Carolina, Tennessee, and Texas.

${ }^{z}$ Northern United States includes Illinois, Indiana, Iowa, Michigan, Minnesota, Nebraska, New York, North Dakota, Ohio, Pennsylvania, South

Dakota, and Wisconsin. 
TABLE 7

Estimated grain contamination (bushels) by mycotoxins in the United States and Ontario, Canada from 2012 to 2015.W

\begin{tabular}{|c|c|c|c|c|c|}
\hline State or province & 2012 & $2013^{x}$ & 2014 & 2015 & Total \\
\hline Arkansas & 12,714 & 16,304 & 0 & 0 & 29,019 \\
\hline Colorado & 0 & 0 & 0 & 0 & 0 \\
\hline Illinois & $525,306,301$ & $57,513,691$ & $51,619,989$ & $44,623,060$ & $679,063,041$ \\
\hline Iowa & $123,439,658$ & 0 & $2,989,519$ & 330,729 & $126,759,906$ \\
\hline Kansas & $409,346,124$ & $5,714,934$ & 63,812 & 0 & $415,124,870$ \\
\hline Kentucky & $3,288,936$ & $1,225,859$ & $1,135,035$ & $1,180,799$ & $6,830,628$ \\
\hline Minnesota & 0 & 0 & $1,340,237$ & 0 & $1,340,237$ \\
\hline Mississippi & 1,336 & 1,478 & 0 & 885 & 3,699 \\
\hline Missouri & $27,317,881$ & - & 0 & 0 & $27,317,881$ \\
\hline Nebraska & $1,220,411,111$ & $1,509,194,169$ & 0 & 0 & $2,729,605,281$ \\
\hline New York & 48,649 & 50,877 & 52,243 & 43,924 & 195,693 \\
\hline North Carolina & 19,672 & 24,874 & 21,183 & 440,228 & 505,958 \\
\hline South Dakota & 0 & 0 & 80,722 & 0 & 80,722 \\
\hline Tennessee & 8,699 & 0 & 0 & 0 & 8,699 \\
\hline Texas & $73,353,961$ & $53,125,000$ & $88,462,155$ & $66,567,381$ & $281,508,496$ \\
\hline Wisconsin & $24,294,479$ & $4,653,638$ & 534,376 & 54,515 & $29,537,008$ \\
\hline Total & $2,607,357,560$ & $1,648,956,590$ & $155,592,532$ & $117,286,671$ & $4,529,193,354$ \\
\hline Southern U.S. ${ }^{y}$ & $513,358,606$ & $60,120,131$ & $89,682,184$ & $68,189,293$ & $731,350,214$ \\
\hline $\begin{array}{l}\text { Northern U.S. }{ }^{\mathrm{z}} \text { and } \\
\text { Ontario, Canada }\end{array}$ & $2,093,998,953$ & $1,588,836,459$ & $65,910,348$ & $49,097,379$ & $3,797,843,140$ \\
\hline
\end{tabular}

${ }^{w}$ In 2013-2015, values are for contamination of grain only, not necessarily yield loss. Data from 2012 may represent either contamination, direct losses due to contamination, or both.

x In 2013, disease loss estimate data was not available in Missouri.

y Southern United States includes Arkansas, Colorado, Kansas, Kentucky, Louisiana, Mississippi, Missouri, North Carolina, Tennessee, and Texas.

${ }^{z}$ Northern United States includes Illinois, Indiana, Iowa, Michigan, Minnesota, Nebraska, New York, North Dakota, Ohio, Pennsylvania, South

Dakota, and Wisconsin. 
TABLE 8

Total estimated corn loss (bushels) by disease or type of disease in the United States and Ontario, Canada from 2012 to 2015.

\begin{tabular}{|c|c|c|c|c|c|c|}
\hline Disease common name & Latin binomial & $2012^{s}$ & $2013^{t}$ & 2014 & 2015 & Total \\
\hline Root rots & 一 & & $70,941,867$ & $32,042,002$ & $59,262,882$ & $162,246,751$ \\
\hline Seedling blights & - & & $148,739,829$ & $69,900,871$ & $48,019,326$ & $266,660,026$ \\
\hline Plant-parasitic nematodes & - & $80,873,420$ & $80,739,079$ & $60,835,205$ & $72,223,455$ & $294,671,158$ \\
\hline Rhizoctonia & Rhizoctonia spp. & $10,468,470$ & - & - & - & - \\
\hline Pythium damping off & Pythium spp. & $93,407,422$ & - & - & - & - \\
\hline $\begin{array}{l}\text { Other root rots/seedling } \\
\text { blights }^{\mathrm{u}}\end{array}$ & - & $1,040,014$ & - & - & - & - \\
\hline Carbonum leaf spot & Cochliobolus carbonum & $12,139,341$ & $3,979,926$ & $8,164,537$ & $4,153,286$ & $28,437,090$ \\
\hline Common rust & Puccinia sorghi & $49,707,925$ & $52,441,997$ & $109,937,337$ & $18,179,858$ & $230,267,117$ \\
\hline Common smut & Ustilago maydis & $83,537,963$ & $24,934,358$ & $13,084,489$ & $7,362,035$ & $128,918,845$ \\
\hline Crazy top & Sclerophthora macrospora & 139,938 & 367,224 & 350,666 & 528,826 & $1,386,654$ \\
\hline Eyespot & Kabatiella zeae & $13,808,658$ & $12,634,760$ & $14,043,426$ & $68,849,094$ & $109,335,939$ \\
\hline Goss's wilt & $\begin{array}{l}\text { Clavibacter michiganensis } \\
\text { subsp. nebraskensis }\end{array}$ & $61,839,925$ & $102,808,589$ & $196,964,925$ & $139,795,799$ & $501,409,237$ \\
\hline Northern corn leaf blight & Setosphaeira turcica & $73,993,728$ & $131,554,916$ & $350,068,129$ & $551,054,156$ & $1,106,670,929$ \\
\hline Physoderma leaf spot & Physoderma maydis & $1,472,043$ & $12,948,855$ & $32,697,398$ & $56,260,881$ & $103,379,177$ \\
\hline Southern corn leaf blight & Bipolaris maydis & 29,988 & 65,460 & 710,175 & $6,194,177$ & $6,999,800$ \\
\hline Southern rust & Puccinia polysora & $53,394,080$ & $57,373,993$ & $23,665,110$ & $138,814,598$ & $273,247,781$ \\
\hline Stewart's disease & Pantoea stewartii & $11,437,901$ & 113,255 & 21,183 & 44,023 & $11,616,362$ \\
\hline Maize Dwarf Mosaic & Maize dwarf mosaic virus & $2,956,805$ & $2,388,425$ & $3,193,218$ & $2,376,599$ & $10,915,046$ \\
\hline $\begin{array}{l}\text { Other virus/virus-like } \\
\text { diseases }^{\vee}\end{array}$ & - & $2,936,653$ & $4,682,762$ & $2,657,138$ & $2,398,524$ & $12,675,077$ \\
\hline $\begin{array}{l}\text { Other foliar/aboveground } \\
\text { diseases }^{\mathrm{w}}\end{array}$ & - & $3,021,902$ & $2,302,025$ & $1,290,500$ & $1,422,138$ & $8,036,565$ \\
\hline Anthracnose stalk rot & Colletotrichum graminicola & $67,073,263$ & $47,527,197$ & $70,296,416$ & $236,122,780$ & $421,019,655$ \\
\hline Fusarium ear rot & Fusarium spp. & $91,386,214$ & $52,127,712$ & $51,647,176$ & $18,921,537$ & $214,082,640$ \\
\hline Gibberella ear rot & Fusarium graminearum & $38,334,993$ & $13,722,470$ & $81,615,500$ & $25,753,873$ & $159,426,836$ \\
\hline Other ear rots ${ }^{y}$ & - & $15,841,624$ & 244,734 & $3,063,777$ & 750,721 & $19,900,855$ \\
\hline Mycotoxin contamination ${ }^{z}$ & - & $2,607,357,560$ & $1,648,956,590$ & $155,592,532$ & $117,286,671$ & $4,529,193,354$ \\
\hline
\end{tabular}

${ }^{\mathrm{s}}$ In 2012, seedling and root rot disease losses were estimated using different categories than in 2013 to 2015.

${ }^{\mathrm{t}}$ In 2013, disease loss estimate data was not available in Missouri.

"Other root rots/seedling blights includes loss due to Phoma terrestris and possibly other disease-causing pathogens.

${ }^{v}$ Other virus/virus-like diseases includes loss due to Brome mosaic virus; Maize chlorotic mottle virus; Maize dwarf mosaic virus + Maize chlorotic dwarf virus complex; Sugarcane mosaic virus; Wheat streak mosaic virus; and possibly others.

${ }^{w}$ Other foliar/aboveground diseases include losses due to Peronosclerospora sorghi; Stenocarpella macrospora; and possibly others.

x Other stalk rots includes Physoderma maydis; Pythium aphanidermatum; and possibly others.

y Other ear rots includes Cladosporium spp.; Nigrospora oryzae; Penicillium spp.; Trichoderma viride; and possibly others.

${ }^{\mathrm{z}}$ In 2013-2015, values are for contamination of grain only, not necessarily yield loss. Data from 2012 may represent either contamination, direct losses due to contamination, or both. 
TABLE 9

Ten most destructive corn diseases and associated estimated yield losses (bushels) by disease or type of disease in the northern United States ${ }^{\mathrm{z}}$ and Ontario, Canada from 2012 to 2015.

\begin{tabular}{|c|c|c|c|c|c|c|c|c|}
\hline \multirow[b]{2}{*}{ Rank } & \multicolumn{2}{|c|}{2012} & \multicolumn{2}{|c|}{2013} & \multicolumn{2}{|c|}{2014} & \multicolumn{2}{|c|}{2015} \\
\hline & Disease & Loss & Disease & Loss & Disease & Loss & Disease & Loss \\
\hline 1 & $\begin{array}{l}\text { Aspergillus ear } \\
\text { rot }\end{array}$ & $99,626,600$ & Seedling blights & $148,580,920$ & $\begin{array}{l}\text { Northern corn } \\
\text { leaf blight }\end{array}$ & $347,593,010$ & $\begin{array}{l}\text { Northern corn } \\
\text { leaf blight }\end{array}$ & $547,671,336$ \\
\hline 2 & Fusarium ear rot & $89,646,682$ & $\begin{array}{l}\text { Northern corn } \\
\text { leaf blight }\end{array}$ & $130,703,478$ & Goss's wilt & $190,067,089$ & $\begin{array}{l}\text { Anthracnose } \\
\text { stalk rot }\end{array}$ & $233,209,053$ \\
\hline 3 & $\begin{array}{l}\text { Pythium damping } \\
\text { off }\end{array}$ & $87,826,356$ & Goss's wilt & $99,875,100$ & Gray leaf spot & $136,701,632$ & Gray leaf spot & $224,420,541$ \\
\hline 5 & $\begin{array}{l}\text { Fusarium stalk } \\
\text { rot }\end{array}$ & $82,742,000$ & Root rots & $70,766,630$ & $\begin{array}{l}\text { Fusarium stalk } \\
\text { rot }\end{array}$ & $101,881,118$ & Southern rust & $129,217,456$ \\
\hline 6 & Gray leaf spot & $80,748,571$ & $\begin{array}{l}\text { Fusarium stalk } \\
\text { rot }\end{array}$ & $60,688,350$ & $\begin{array}{l}\text { Gibberella stalk } \\
\text { rot }\end{array}$ & $86,127,279$ & $\begin{array}{l}\text { Fusarium stalk } \\
\text { rot }\end{array}$ & $116,756,288$ \\
\hline 7 & $\begin{array}{l}\text { Northern corn } \\
\text { leaf blight }\end{array}$ & $70,891,165$ & Southern rust & $54,588,852$ & $\begin{array}{l}\text { Gibberella ear } \\
\text { rot }\end{array}$ & $80,237,937$ & $\begin{array}{l}\text { Gibberella } \\
\text { stalk rot }\end{array}$ & $89,298,666$ \\
\hline 10 & $\begin{array}{l}\text { Plant-parasitic } \\
\text { nematodes }\end{array}$ & $55,202,729$ & $\begin{array}{l}\text { Fusarium ear } \\
\text { rot }\end{array}$ & $50,674,749$ & $\begin{array}{l}\text { Anthracnose } \\
\text { stalk rot }\end{array}$ & $57,275,846$ & Root rots & $55,007,881$ \\
\hline
\end{tabular}

${ }^{z}$ Northern United States includes Illinois, Indiana, Iowa, Michigan, Minnesota, Nebraska, New York, North Dakota, Ohio, Pennsylvania, South Dakota, and Wisconsin.

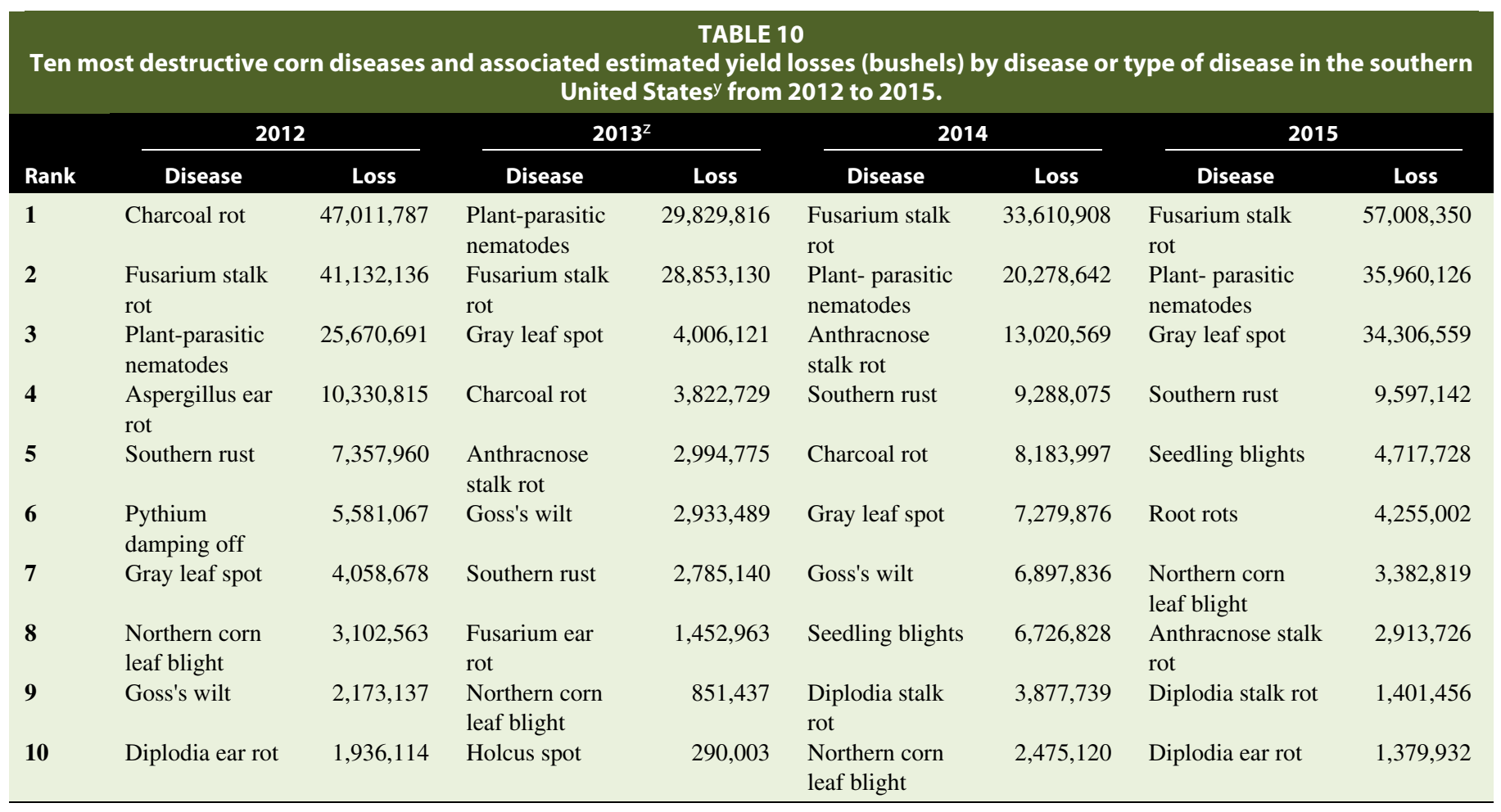

y Southern United States includes Arkansas, Colorado, Kansas, Kentucky, Louisiana, Mississippi, Missouri, North Carolina, Tennessee, and Texas.

${ }^{\mathrm{z}}$ In 2013, disease loss estimate data was not available in Missouri. 

excluding grain contamination or rejection due to mycotoxins.

\begin{tabular}{|c|c|c|c|c|c|}
\hline State of province & 2012 & $2013^{x}$ & 2014 & 2015 & Total \\
\hline Arkansas & $\$ 23,377,754$ & $\$ 6,260,841$ & $\$ 3,842,448$ & $\$ 8,085,869$ & $\$ 41,566,912$ \\
\hline Colorado & $41,103,333$ & $1,376,243$ & $19,939,660$ & 99,846 & $62,519,083$ \\
\hline Illinois & $1,474,474,835$ & $904,667,356$ & $857,007,963$ & $798,083,426$ & $4,034,233,580$ \\
\hline Iowa & $1,248,559,224$ & $735,531,605$ & $2,308,061,040$ & $2,805,901,584$ & $7,098,053,452$ \\
\hline Kansas & $748,589,076$ & $303,045,216$ & $271,843,806$ & $431,782,550$ & $1,755,260,649$ \\
\hline Kentucky & $38,914,666$ & $9,674,843$ & $4,203,716$ & $41,190,980$ & $93,984,206$ \\
\hline Minnesota & $298,171,227$ & $696,290,911$ & $581,523,337$ & $379,729,596$ & $1,955,715,070$ \\
\hline Mississippi & $17,159,009$ & $8,589,842$ & $5,542,624$ & $10,842,075$ & $42,133,551$ \\
\hline Missouri & $188,482,450$ & - & $112,211,445$ & $76,973,526$ & $377,667,422$ \\
\hline Nebraska & $983,507,778$ & $722,229,359$ & $209,343,944$ & $691,424,574$ & $2,606,505,654$ \\
\hline New York & $41,889,930$ & $32,655,109$ & $15,803,140$ & $14,784,976$ & $105,133,154$ \\
\hline North Carolina & $18,098,957$ & $11,165,538$ & $12,381,561$ & $23,889,435$ & $65,535,491$ \\
\hline South Dakota & $906,058,912$ & $177,262,961$ & $66,324,213$ & $301,051,620$ & $1,450,697,705$ \\
\hline Tennessee & $39,265,433$ & $14,680,241$ & $12,544,830$ & $13,573,322$ & $80,063,825$ \\
\hline Texas & $11,191,719$ & $2,184,500$ & $1,564,010$ & $1,326,023$ & $16,266,252$ \\
\hline Wisconsin & $601,361,227$ & $113,940,613$ & $180,622,819$ & $180,718,006$ & $1,076,642,665$ \\
\hline Total & $\$ 8,978,097,068$ & $\$ 4,758,585,782$ & $\$ 6,067,786,421$ & $\$ 7,599,147,333$ & $\$ 27,403,616,604$ \\
\hline Southern U.S.y & $\$ 1,134,028,611$ & $\$ 361,654,437$ & $\$ 448,706,709$ & $\$ 610,839,759$ & $\$ 2,555,229,515$ \\
\hline $\begin{array}{l}\text { Northern U.S. }{ }^{\mathrm{z}} \text { and } \\
\text { Ontario, Canada }\end{array}$ & $\$ 7,844,068,458$ & $\$ 4,396,931,346$ & $\$ 5,619,079,712$ & $\$ 6,988,307,574$ & $\$ 24,848,387,089$ \\
\hline
\end{tabular}

x In 2013, disease loss estimate data was not available in Missouri.

y Southern United States includes Arkansas, Colorado, Kansas, Kentucky, Louisiana, Mississippi, Missouri, North Carolina, Tennessee, and Texas.

${ }^{z}$ Northern United States includes Illinois, Indiana, Iowa, Michigan, Minnesota, Nebraska, New York, North Dakota, Ohio, Pennsylvania, and South

Dakota, and Wisconsin.

Losses due to disease may be underestimated. The costs to diagnose and manage diseases are additional disease-related corn production expenses that are often not included in economic estimates of losses due to disease. Disease diagnostic costs include scouting fields, fees for consultant or diagnostic services, quantification of nematode population densities from soil samples, and costs associated with misdiagnosis. Management for various corn diseases includes hybrid resistance, crop rotation, tillage, fungicide/nematicide-treated seed, nematicide, foliar fungicide, insect/vector and alternative host plant management, and proper post-harvest handling (Munkvold and White 2016). For example, estimated application cost for foliar fungicide from 2008 to 2012 was \$28.25/acre (Liu et al. 2015). However, cost of fungicide product and application undoubtedly vary by region, supplier, product selected, and method of application. Additional costs incurred because of corn disease include refusal of corn seed for export due to contamination with a quarantined pathogen, phytosanitary inspections, breeding corn for resistance, grain quality reduction that results in livestock health issues, and increased harvest difficulty due to lodging (Pataky 2003; Wise et al. 2016; Munkvold and White 2016).

Corn disease risk is not static, and varies greatly over time and by location based on many factors. For example, changing weather patterns that result in increased humidity, frequent and heavy rainfall events, and changes in temperature may heighten the risk of some corn diseases. Other factors increasing the risk of disease include: (i) reduced tillage and continuous corn production practices that increase inoculum-infested crop residue on the soil surface; (ii) increasing use of greater plant populations; and (iii) selecting hybrids based on high yield potential rather than disease resistance (Butzen and Jeschke 2013; Wise and Mueller 2011). Thus, it is possible that crop yield reduction and costs associated with disease management will increase, resulting in an increased need for ongoing scientific research on corn pathogens and farmer /agribusiness education regarding corn diseases. Our survey results will help scientists, government, and educators direct research, funding, and educational efforts in corn pathology and disease management.

\section{AUTHOR'S NOTE}

The values in this publication are intended to be estimates of corn yield loss due to diseases. The members of the United States and Canadian Corn Disease Working Group used the most appropriate means available to estimate disease losses and assume no liability resulting from the use of these estimates. This information is only a guide.

\section{ACKNOWLEDGMENTS}

Special thanks to the many people and agribusinesses that supplied information to help inform the disease loss estimates made by members of the Corn Disease Working Group. Ontario participation was supported by the Grain Farmers of Ontario who obtained funding, in part, through "Growing Forward 2" (GF2), a federal-provincial-territorial initiative. The Agricultural Adaptation Council assists in the delivery of GF2 in Ontario. 


\section{LITERATURE CITED}

Bennett, J. W., and Klich, M. 2003. Mycotoxins. Clin. Microbiol. Rev. 16:498-516.

Butzen, S., and Jeschke, M. 2013. Agronomy Sciences Research Summary: Canadian Edition. DuPont Pioneer.

Jardine, D. 2006. Stalk rots of corn and sorghum. L-741. Agric. Exp. Station and Coop. Ext. Service. Kansas State Univ., Manhattan, KS.

Koenning, S. R., and Wrather, J. A. 2010. Suppression of soybean yield potential in the continental United States by plant diseases from 2006 to 2009. Plant Health Prog. doi:10.1094/PHP-2010-1122-01-RS.

Kulasekera, K. 2015. Estimated area, yield, production and farm value of specified field crops, Ontario, 2011-2015. Ontario Ministry of Agric., Food, and Rural Affairs, Guelph. http://www.omafra.gov.on.ca/english/ stats/crops/estimate new.htm.

Lui, Y., Langemeier, M., and Wise, K. 2015. Economic benefits of fungicide use in corn production. South. Agric. Econ. Assoc. Ann. Mtng., Atlanta, GA, 31 Jan.-3 Feb. 2015.

Munkvold, G. P., and White, D. G. 2016. Compendium of Corn Diseases. 4th ed. American Phytopathological Society, St. Paul, MN.

NOAA (National Oceanic and Atmospheric Administration). 2015. Quarterly Climate Impacts and Outlook. Midwest Region. September 2015

Norton, D. C., and Nyvall, R. F. 2011 Review. Nematodes that Attack Corn in Iowa. PM 1027. Iowa State University Extension, Ames.

Pataky, J. 2003. Stewart's wilt of corn. Online. APS Features. doi:10.1094/APSnetFeature-2003-0703.
Plastina, A., and Johanns, A. 2016. 2014 Iowa Farm Costs and Returns. FM 1789. Iowa State University Ext., Ames.

Ullstrup, A. J. 1972. The impacts of the southern corn leaf blight epidemics of 1970-1971. Annu. Rev. Phytopathol. 10:37-50.

USDA-NASS. United States Dept. of Agric., National Agric. Statistics Service. Quick Stats 2.0. http://www.nass.usda.gov/Quick_Stats.

Wise, K. and Mueller, D. 2011. Are fungicides no longer just for fungi? An analysis of foliar fungicide use in corn. APS Features. doi:10.1094/APSnetFeature-2011-0531.

Wise, K. A., Mueller, D. S., Sisson, A. J., Smith, D. L., Bradley, C. A., and Robertson, A. E. 2016. A Farmers' Guide to Corn Diseases. American Phytopathological Society Press, St. Paul, MN.

Wrather, J. A., Chambers, A. Y., Fox, J. A., Moore, W. F., and Sciumbato, G. L. 1995. Soybean disease loss estimates for the southern United States, 1974-1994. Plant Dis. 79:1076-1079.

Wrather, J. A., and Koenning, S. R. 2006. Estimates of disease effects on soybean yields in the United States 2003 to 2005. J. Nematol. 38:173-180.

Wrather, J. A., and Koenning, S. R. 2009. Effects of diseases on soybean yields in the United States 1996 to 2007. Plant Health Prog. doi:10.1094/PHP-2009-0401-01-RS.

Wrather, J. A., Koenning, S. R., and Anderson, T. R. 2003. Effect of diseases on soybean yields in the United States and Ontario (1999-2002). Plant Health Prog. doi:10.1094/PHP-2003-0325-01-RV.

Wrather, J. A., Stienstra, W. C., and Koenning, S. R. 2001. Soybean disease loss estimates for the United States from 1996-1998. Can. J. Plant Pathol. 23:122-131. 